\title{
BMJ Global Health Changing views on child mortality and economic sanctions in Iraq: a history of lies, damned lies and statistics
}

To cite: Dyson T, Cetorelli V. Changing views on child mortality and economic sanctions in Iraq: a history of lies, damned lies and statistics. BMJ Glob Health 2017;2:e000311. doi:10.1136/ bmjgh-2017-000311

Received 6 February 2017 Revised 29 March 2017 Accepted 31 March 2017

\section{CrossMark}

${ }^{1}$ Department of International Development, London School of Economics, London, UK ${ }^{2}$ Middle East Centre, London School of Economics, London, UK

Correspondence to Professor Tim Dyson; t.dyson@|se.ac.uk

\section{ABSTRACT}

In August 1990, Saddam Hussein's army invaded Kuwait and consequently the United Nations imposed economic sanctions on Iraq. In 1991, an international military alliance expelled the Iraqi army from Kuwait during a short war. Nevertheless, the economic sanctions remained in placetheir removal required that Iraq should destroy its weapons of mass destruction. Subsequent years saw reports of acute suffering in Iraq. The sanctions undoubtedly greatly reduced the country's ability to import supplies of food and medicine. Particular concerns arose about the state of young children. These concerns crystalised in 1999 when, with cooperation from the Iraqi government, Unicef conducted a major demographic survey. The results of the survey indicated that the under- 5 death rate in Iraq had increased hugely between 1990 and 1991 and had then continued at a very high level. The survey results were used both to challenge and support the case for the invasion of Iraq in 2003. And they were cited by Tony Blair in 2010 in his testimony to the Iraq Inquiry established by the British government. Indeed, the results of the 1999 Unicef/Government of Iraq survey are still cited. Since 2003, however, several more surveys dealing with child mortality have been undertaken. Their results show no sign of a huge and enduring rise in the under- 5 death rate starting in 1991. It is therefore clear that Saddam Hussein's government successfully manipulated the 1999 survey in order to convey a very false impression-something that is surely deserving of greater recognition.

\section{INTRODUCTION}

It is sometimes said that we live in a world of 'post-fact' politics - a world in which the truth is always trying to keep up with disinformation. In this context, the present article addresses the creation of a remarkable fiction-in particular that, following the imposition of strict economic sanctions on Iraq by the United Nations (UN) Security Council in 1990, the country's child (ie, under-5) mortality rate almost doubled and subsequently remained at a very high level. The deception was manufactured by the then government of Iraq led by Saddam Hussein. Its purpose was to shake international opinion so that the UN economic sanctions would be lifted. Following its creation and dissemination the deception received considerable attention

\section{Key questions}

What is already known about this topic?

- It is widely believed that child mortality in Iraq during 1991-2003 was unusually high compared to the 1980s.

What are the new findings?

- Surveys undertaken since 2003 find no evidence of unusually high levels of child mortality during 1991 2003.

- The government of Iraq cleverly manipulated survey data to fool the international community.

- There has been no substantial reduction in child mortality in the period since 2003.

- Child mortality in Iraq remains about twice the level of most neighbouring countries.

Recommendations for policy

- Statistics generated in situations conditioned by conflict and strong political contestation should always be interpreted with great care.

and was widely believed to be true. Moreover, it continues to be influential. Yet, as this article documents, in the period since the invasion of Iraq in 2003 there has been an accumulation of evidence that has exposed the fiction. Unfortunately, however, the more mundane truth that has emerged has received much less attention than the original spectacular lie.

\section{BACKGROUND}

Saddam Hussein became president of Iraq in 1979. He then launched an attack on Iran which led to the major 1980-1988 Iran/Iraq war. At the end of this conflict Iraq was deeply in debt, and this was one factor behind Iraq's invasion of Kuwait in August 1990.

The invasion of Kuwait by Saddam Hussein's army immediately led to the imposition of stringent economic sanctions on Iraq by the UN Security Council. Because Iraq imported roughly $70 \%$ of its food supplies, the government responded very quickly by instigating a system of household food 
rationing. Then, during a 6-week war early in 1991, a military alliance led by the USA ejected the Iraqi army from Kuwait. Saddam Hussein's regime faced two major uprisings, however. A rebellion of Shiites in the south of Iraq was crushed. But an uprising of Kurds in the north proved more successful. As a result, in September 1992 Saddam withdrew his army from three northern governorates-containing 15\%-20\% of Iraq's people-which then became an autonomous Kurdish area. Nevertheless, the UN economic sanctions stayed in place for the $80 \%-85 \%$ of people who lived in the centre and south which continued to be under the government's control.

The 1990s saw increasing international concern about the extremely harsh living conditions that were being endured by Iraq's people-especially those living in the centre and south. The country's infrastructure had been badly damaged by aerial bombing during the 6 -week war, and among other things this seriously affected the provision of supplies of clean water, electricity and also sewage disposal. On top of this, the economic sanctions greatly restricted Iraq's ability to export oil so that it could pay for important imports-especially of food, but also of medicine. As the 1990s progressed, it was clear that many aspects of life were being seriously affected by the continuing UN economic sanctions.

\section{INITIAL STUDIES OF CHILD MORTALITY}

Reports and letters in prominent medical journals were influential in shaping international opinion about the circumstances in Iraq. Thus, soon after the war in early 1991 a group of researchers based in the USA made a rapid assessment of children's health and health services and found 'suffering of tragic proportions.' ${ }^{2}$ A little later, another set of researchers known as the International Study Team (IST) conducted a nationally representative household survey of child mortality. The survey was held during a 2-week period in late 1991 and asked questions about births that had occurred to women after 1 January 1985. The analysis of the data was based on a total of 16076 live births and 768 deaths. On this basis, the IST estimated that the under-5 mortality rate (U5MR) in the 5 years before 1 January 1991 was about 43 child deaths per 1000 live births, and that in the ensuing 8 months to 31 August 1991 it was around 128 per 1000 . The IST estimated that during these 8 months-a period which, in addition to the economic sanctions, the country was affected by the war, aerial bombing, internal rebellions and mass migration-there were 46900 excess child deaths compared with what would have occurred had mortality stayed at the level indicated for $1985-1990 .^{3}$ The greatest increase in U5MR was recorded in the Kurdish north. The IST acknowledged sources of potential bias in the survey, in particular the missing date of death for a substantial proportion of children and the possible omission of deaths occurring before 1990 .

With the sanctions continuing, in 1995 a letter reported the results of a small survey conducted in Baghdad in that year under the auspices of the UN's Food and Agriculture Organization (FAO), in cooperation with Saddam Hussein's government which provided the field staff. The FAO survey interviewed households that had been included in the IST survey in 1991. The U5MRs reported in the letter also suggested that there had been a huge rise in child mortality-from 33 child deaths per 1000 births before the sanctions to around 245 per 1000 afterwards. The authors hazarded an estimate of 567000 child deaths as a consequence of the sanctions. ${ }^{4}$ This figure attracted attention and influenced international opinion. ${ }^{5}$ However, a second letter published in 1997 from one of the first letter's authors was more cautious. It told of return visits made to Baghdad in 1996 and 1997 during which women who in 1995 had reported child deaths were reinterviewed. During these return visits, each interview team had an international supervisor and a Jordanian interviewer in addition to the field staff supplied by the Iraqi government. Significantly, many of the deaths were not confirmed in the reinterviews. Moreover, it emerged that some miscarriages and stillbirths had been wrongly classified as child deaths in 1995. ${ }^{6}$ However, these important points of qualification received relatively little attention. ${ }^{5}$

Meanwhile there was mounting debate in international circles as to who was responsible for the misery in Iraq. Some commentators blamed the government of Saddam Hussein. However, other observers attributed responsibility to countries like the USA and the UK which most supported maintaining the economic sanctions. One result of the debate was that in April 1995 the UN Security Council passed the first of several resolutions aimed at improving conditions in Iraq by permitting the sale of oil so that food and medicine could be imported. This became known as the Oil-for-Food Programme (OFFP). But the negotiations with Saddam Hussein's government to implement the OFFP were very slow. Eventually, however, one close observer of the situation was able to comment that '[s]ince March 1998 the oil for food programme has greatly increased access to essential supplies and the mortality rate [of children under 5] has surely declined. ${ }^{7}$

\section{THE IRAQ CHILD AND MATERNAL MORTALITY SURVEY}

In February to May 1999, Unicef was allowed to conduct a major national survey focused on child mortality. This was the Iraq Child and Maternal Mortality Survey (ICMMS). The ICMMS was similar to household surveys that have been undertaken in many countries. However, because of the political situation in Iraq it was conducted concurrently as two parallel surveys. Thus, in the autonomous Kurdish north the ICMMS was supervised directly by Unicef. But in the centre and south, Unicef conducted the ICMMS in cooperation with Saddam Hussein's government.

Whereas the earlier IST and FAO surveys had been quite limited in various respects-for example, in terms 
of their sample sizes and time depth-the ICMMS represented a significant advance. For example, the sample was large, being about 14000 households in the north and 24000 in the centre/south. Also, the ICMMS focused on child mortality - with little other information being gathered. In the centre and south, the government of Iraq provided the field staff from the health sector. The interviewers, all women, were either junior doctors or recent medical graduates, and considerable effort was made to train them. The ICMMS questionnaire was comparable to that used in other countries, and it was pretested carefully. Full, rather than truncated, birth histories were collected from ever-married women aged 15-49. Lastly, Unicef established an independent panel of experts to assess the ICMMS survey procedures and data quality. The panel identified no problems. ${ }^{8}$

In August 1999, Unicef released the preliminary findings of the ICMMS with considerable publicity. The survey results indicated that children in the centre/ south of Iraq were dying at over twice the rate of 10 years earlier. Unicef's Executive Director noted that there was an ongoing humanitarian emergency in the country and that there would have been 500000 fewer child deaths during 1991-1998 had the fall in mortality of the 1980s continued throughout 1991-1998. Concern was understandably expressed that whenever economic sanctions are imposed on a country they should be designed and executed so that they do not have a negative impact on children. ${ }^{9}$

In 2000, an article titled 'Sanctions and childhood mortality in Iraq' presented a detailed analysis of the ICMMS data. The article contained estimates of child mortality by 5 -year periods. The authors estimated that between 1984-1989 and 1994-1999, the U5MR rose from 56 to 131 deaths per $1000 .{ }^{8}$ A subsequent article provided annual estimates. ${ }^{10}$ For the centre/south, the results indicated a rise in the U5MR from 59 to 116 per 1000 between 1990 and 1991, with a further increase to 142 per 1000 by 1998 . For the north, the U5MR rose from 72 to 128 per 1000 between 1987 and 1991. With its onset well before 1991, however, this rise mainly reflected Saddam Hussein's persecution of the Kurds-recall in this context that the poison gas attack on the Kurdish town of Halabja took place in 1988. In the north, with the Iraqi army withdrawn, the ICMMS results suggested that the U5MR fell back sharply to 68 per 1000 in 1993.

The ICMMS results for the centre/south of Iraq indicating that there was a huge rise in child mortality between 1990 and 1991 and sustained high mortality thereafter were generally thought to be reliable and were widely cited. The results were used to warn against the potentially disastrous consequences of the US/UK invasion of Iraq in 2003. ${ }^{11}$ And they were also used as justification for that invasion by its proponents. Thus, giving evidence to the Iraq Inquiry, chaired by Sir John Chilcot, Tony Blair stated in 2010 that during 2000-2002 (ie, before the invasion) those living under
Saddam Hussein's regime 'had a child mortality rate of 130 per 1000 children under the age of five ... That equates to roughly about 90000 deaths under the age of five a year. The figure today is not 130 , it is $40 \ldots$ that's the result that getting rid of Saddam makes. ${ }^{, 12}$

It is now known, however, that the ICMMS results for the centre/south of Iraq were a deception. ${ }^{5}{ }^{13}$ But this fact has received virtually no publicity or attention. Unicef has neither acknowledged the error nor made the ICMMS data publicly available. Indeed, the article containing the detailed analysis of the ICMMS estimates by 5-year periods, and its conclusion that there was a sharp rise in mortality due to the sanctions, remain widely cited. ${ }^{14-22}$ Yet the UN unobtrusively changed its own U5MR estimates in $2009 .{ }^{2324}$ We now consider how the deception was revealed.

\section{UNCOVERING THE DECEPTION}

Following the US/UK invasion of Iraq in March 2003, there was concern in the coalition's military occupation authorities to assemble information on Iraq's population. In this context, it became known that a census had been undertaken in the centre and south of Iraq in 1997. Moreover, the census had included some very basic questions on child mortality. A copy of the census report was unearthed and forwarded to the US Census Bureau in Washington, DC. And, significantly, an article published in the New York Times in August 2003 quoted a Census Bureau official as stating that 'it looks like child mortality may not have been quite as high during the mid-to-late 1990 s as has been thought. ${ }^{, 25}$

Then, in 2005, the report of a Working Group of an Independent Inquiry Committee established by the Secretary General of the UN to investigate the OFFP was published. This report contained an analysis of the child mortality data from the 1997 census. ${ }^{26}$ The data suffered

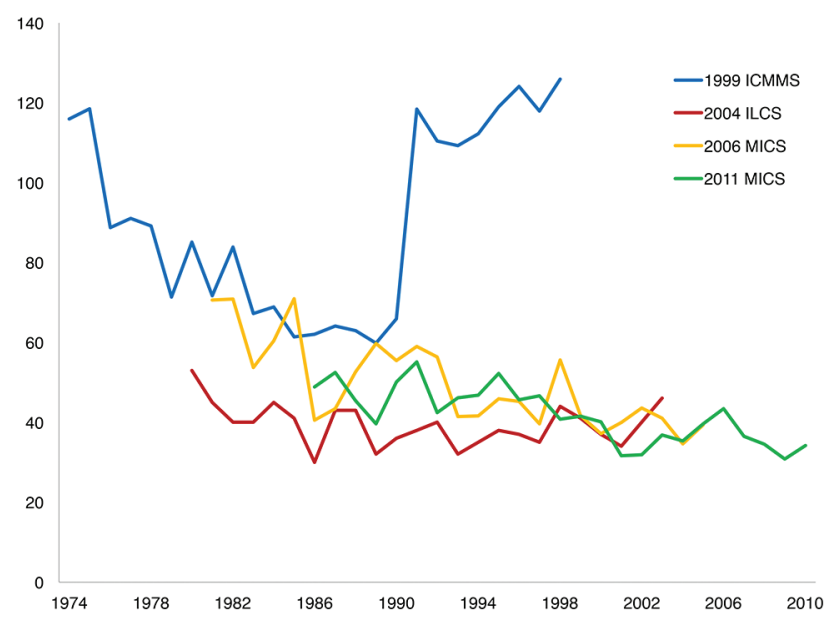

Figure 1 Annual estimates of the child mortality rate in Iraq from four retrospective surveys (under-5 deaths per 1000 live births), 1974-2010. ICMMS, Iraq Child and Maternal Mortality Survey; ILCS, Iraq Living Conditions Survey; MICS, Multiple Indicator Cluster Survey. 
from serious errors and limitations. Nevertheless, and to some surprise, the Working Group questioned whether there had been a huge rise in child mortality around 1991 as was indicated by the IST and, more especially, the ICMMS. The Working Group suggested that the Iraqi government might have tampered with the ICMMS data. These ideas were rejected by those who saw no reason to question the ICMMS child mortality estimates on the basis of the 1997 census data. ${ }^{27} 28$

However, since 2003 three major household surveys covering the whole of Iraq and collecting full birth histories from adult women have been conducted. The first survey was the 2004 Iraq Living Conditions Survey (ILCS). The ILCS was funded by the United Nations Development Programme and organised with Norwegian technical assistance. The main purpose of the ILCS was to provide general socioeconomic data. But it also collected birth histories from women in 21000 Iraqi households. When the birth history data began to arrive from the field, the organisers of the survey decided that child deaths were being greatly under-reported. Accordingly, they resolved 'to re-interview all households again with (a) small questionnaire' containing the birth history. ${ }^{29}$ Nevertheless, the U5MRs for 1999-2003 obtained from the reinterviews were still surprisingly low. Indeed, in its report of 2005, even the Working Group of the Independent Inquiry Committee largely dismissed the ILCS results.

The second major survey was the 2006 Multiple Indicator Cluster Survey (MICS). ${ }^{30}$ This entailed collaboration between Unicef and Iraq's Ministry of Health, and it collected birth histories from women in 18000 households. The third survey was the 2011 MICS. This involved a similar collaboration and interviewed women in about 36000 households. $^{31}$ It should be noted that the MICS surveys developed by Unicef have been used in over 60 countries to provide key indicators relating to the state of young children.

With this as background, figure 1 compares the U5MRs calculated from the ICMMS of 1999, the ILCS of 2004, and the MICS surveys of 2006 and 2011. It shows that, in contrast to the ICMMS, the U5MRs from the three recent surveys reveal no sign of a huge rise in child mortality after 1990. This is compelling evidence that it simply did not happen. In short, as suggested with notable intuition by the Working Group of the Independent Inquiry Committee in 2005, the ICMMS data were evidently rigged to show a huge and sustained-and largely non-existent-rise in child mortality. The falsification might have occurred during the data entry stage at the behest of the Iraqi government. However, recall that the government provided the field staff for the ICMMS in the centre and south, so it may be that under the strong-arm influence of government authorities the deception happened during the fieldwork stage (as seems to have occurred during the much smaller 1995 FAO survey in Baghdad). The objective of Saddam Hussein's government was to heighten international concern and so get the economic sanctions ended.
That is not to say that there was no rise at all in the U5MR in Iraq between 1990 and 1991. All three major surveys conducted since 2003 suggest that there was a slight increase. Moreover, recall the substantial rise indicated by the ICMMS for the period 1988-1992 in the north-reflecting the oppression of the Kurds. In this context, the rise indicated for January to August 1991 by the modest IST survey was also much greater in the north. That said, for Iraq as a whole the IST survey probably understated the level of child mortality that prevailed during 1985-1990 and overstated the level during 1991.

If we ignore the-false-U5MRs for 1991-1998 from the ICMMS in figure 1, and take account of the fact that older women are more likely to under-report child deaths (indicated most clearly in figure 1 by the U5MRs from the ILCS for the 1980s) then a significant degree of agreement actually emerges. The three surveys conducted since 2003 all put the U5MR in Iraq during 1995-2000 in the vicinity of 40 per 1000 . In relation to the difficult conditions of the 1990s, it should be noted that Saddam Hussein's government became increasingly proficient at evading the sanctions and Iraq's basic food rationing system probably also helped the situation.

Lastly, for 1970-2015 figure 2 plots the UN's latest U5MR estimates by 5-year periods for Iraq and neighbouring countries. ${ }^{32}$ The estimates for Iraq are based mainly on the 2004, 2006 and 2011 surveys we have discussed, with consideration of the ICMMS results for before 1990. In the 1970s, there was considerable variation in child mortality, the trend in Iraq broadly paralleling the trends in Syria and Jordan. From the early 1980s onwards, however, progress in Iraq seems to have been much slower. Indeed, by 2010-2015 the U5MR in Iraq was roughly twice that of the other countries. The period of miserable progress in reducing child mortality broadly corresponds to the period of Saddam Hussein. He brought a host of troubles and disasters to his country of which, however evaluated, the economic sanctions constituted a very small part.

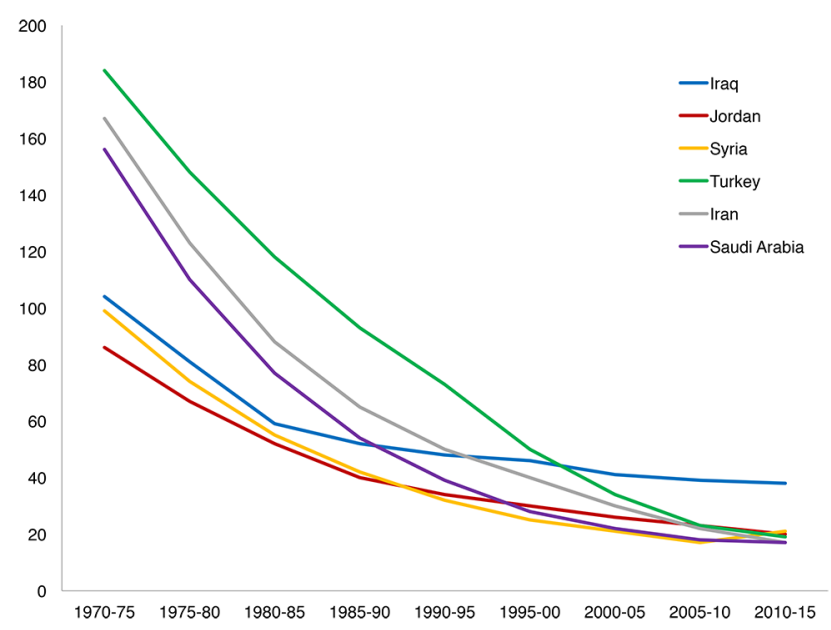

Figure 2 United Nations estimates of the child mortality rate in Iraq and neighbouring countries by 5-year periods, 1970-2015. 


\section{CONCLUSION}

The purpose of this article has been to discuss a major deception. In part, the deception gained credence in the international community because it fitted with the widespread view that the UN's economic sanctions were wrong. That said, there was no major rise in child mortality in Iraq after 1990 and during the period of the sanctions. Conversely, there was no major improvement in child mortality after the downfall of Saddam Hussein. In this context, a rare instance in which the fact of the deception has been twigged appears in the Iraq Inquiry report published in 2016. With reference to Tony Blair's statement about the level of child mortality prevailing before 2003, and its subsequent major decline, Sir John Chilcot and his colleagues clearly decided that the rates for before 2003, based on the ICMMS, were greatly inflated. ${ }^{33} 34$

In conclusion, the rigging of the 1999 Unicef survey was an especially masterful fraud. That it was a deception is beyond doubt, although it is still not generally known. However, when the UN realised its mistake it led to a sudden and large upward revision of its estimate of life expectation in Iraq during 2000-2005, from 57 to 70 years. ${ }^{23} 24$

Acknowledgements This work benefitted from past discussions with Ken Hill, Mike Murphy, Jon Pedersen and Michael Spagat. We thank the anonymous reviewers for helpful comments. Of course, the usual disclaimer applies.

Contributors TD drafted the first version with inputs from VC. Both authors approved the final version.

Competing interests None declared.

Patient consent Obtained.

Provenance and peer review Not commissioned; externally peer reviewed.

Data sharing statement The data used in this article are all available from the references cited.

Open Access This is an Open Access article distributed in accordance with the Creative Commons Attribution Non Commercial (CC BY-NC 4.0) license, which permits others to distribute, remix, adapt, build upon this work non-commercially, and license their derivative works on different terms, provided the original work is properly cited and the use is non-commercial. See: http://creativecommons.org/ licenses/by-nc/4.0/

(C) Article author(s) (or their employer(s) unless otherwise stated in the text of the article) 2017. All rights reserved. No commercial use is permitted unless otherwise expressly granted.

\section{REFERENCES}

1. Towle P. Cold war. The Oxford history of Modern War: Oxford University Press, 2005.

2. Harvard Study Team. The effect of the Gulf crisis on the children of Iraq. N Engl J Med 1991:325:977-80.

3. Ascherio A, Chase R, Coté T, et al. Effect of the Gulf War on Infant and Child Mortality in Iraq. N Engl J Med Overseas Ed 1992;327:931-6.

4. Zaidi S, Fawzi MC. Health of Baghdad's children. The Lancet 1995;346:1485.

5. Spagat $M$. Truth and death in Iraq under sanctions. Signif 2010;7:116-20.

6. Zaidi S. Child mortality in Iraq. The Lancet 1997;350:1105.
7. Garfield R. Morbidity and mortality among iraqi children from 1990 through 1998: assessing the impact of the Gulf war and economic sanctions. $1999 \mathrm{http} / / /$ reliefweb.int/sites/reliefweb.int/files/resources/ A2E2603E5DC88A4685256825005F211D-garfie17.pdf.

8. Ali MM, Shah IH. Sanctions and childhood mortality in Iraq. The Lancet 2000;355:1851-7.

9. UNICEF. Iraq surveys show 'humanitarian emergency'. 1999 www. unicef.org/newsline/99pr29.htm.

10. Blacker J, Jones G, Ali MM. Annual mortality rates and excess deaths of children under five in Iraq, 1991-98. Popul Stud- J Demog 2003;57:217-26.

11. Gordon D. Iraq, war and morality. Econ Polit Weekly 2003;38:1117-20.

12. Blair T. Transcript of evidence given to the Iraq Inquiry on 29 January 2010. http://www.iraqinquiry.org.uk/media/229766/2010-01-29transcript-blair-s1.pdf.

13. Dyson T. New evidence on child mortality in Iraq. Econ Polit Weekly 2009;44:56-9.

14. Ahmadi AM, Meskarpou-Amiri M. The public health effects of economic sanctions as a global concern in $21^{\text {st }}$ century. Journal of Health Policy and Sustainable Health 2015;2:145-6.

15. Karimi M, Haghpanah S. The effects of economic sanctions on disease specific clinical outcomes of patients with thalassemia and hemophilia in Iran. Health Policy 2015;119:239-43.

16. Afesorgbor SK, Mahadevan R. The impact of economic sanctions on Income Inequality of target states. World Dev 2016;83:1-11.

17. Batniji R, Khatib L, Cammett M, et al. Governance and health in the Arab world. The Lancet 2014;383:343-55.

18. Devakumar D, Birch M, Osrin D, et al. The intergenerational effects of war on the health of children. BMC Med 2014;12:57.

19. Gorji A. Sanctions against Iran: the impact on Health Services. Iran $J$ Public Health 2014;43:381-2.

20. Neuenkirch M, Neumeier F. The impact of UN and US economic sanctions on GDP growth. Eur J Polit Econ 2015;40:110-25.

21. Neuenkirch M, Neumeier $F$. The impact of US sanctions on poverty. $J$ Dev Econ 2016;121:110-9.

22. Shin SS. Two Koreas and public health: 'first, do no harm'. Int J Epidemiol 2014;43:1340-1.

23. United Nations World Population Prospects: the 2006 Revision, 2007. United Nations Population Division.

24. United Nations. World Population Prospects: the 2008 Revision, 2009. United Nations Population Division.

25. Barringer F. Fewer Iraqi men: dead or unaccounted? New York Times. 8 Aug 2003. http://www.nytimes.com/2003/08/08/world/ after-the-war-population-puzzle-fewer-iraqi-men-dead-orundercounted.html.

26. Mason JB, Brun T, Chen J, et al. Impact of the Oil-for-Food Programme on the iraqi people: report of an independent Working Group established by the Independent Inquiry Committee appointed to investigate the United Nations Oil-for-Food Programme. 2005 http://reliefweb.int/report/iraq/impact-oil-food-programme-iraqipeople.

27. Blacker J, Ali MM, Jones G. A response to criticism of our estimates of under-5 mortality in Iraq, 1980-98. Pop Stud- J Demog 2007;61:7-13.

28. Dyson T. Child mortality in Iraq since 1990. Econ Polit Weekly 2006;41:4487-96.

29. Iraq Ministry of Planning and Development Cooperation. Iraq Living Conditions Survey 2004: Analytical Report 2005.

30. Iraq Central Organization for Statistics \& Information Technology and Kurdistan Regional Statistics Office. Iraq Multiple Indicator Cluster Survey 2006, Final Report, 2007. https://mics-surveys-prod. s3.amazonaws.com/MICS3/Middle\%20East\%20and\%20North\% 20Africa//raq/2006/Final//raq\%202006\%20MICS English.pdf.

31. Iraq Central Statistics Organization, Kurdistan Regional Statistics Office, Ministry of Health, United Nations Children's Fund. Iraq Multiple Indicator Cluster Survey 2011, Final Report, 2012. https:// mics-surveys-prod.s3.amazonaws.com/MICS4/Middle\%20East\% 20and\%20North\%20Africa//raq/2011/Final//raq\%202011\%20MICS_ English.pdf.

32. United Nations Population Division. World Population Prospects, the 2015 Revision, 2016

33. The Report of the Iraq Inquiry, Section 17, Civilian Casualties. 2016 http://www.iraqinquiry.org.uk.

34. Spagat M. How Tony Blair fumbled Iraq's child mortality statistics. The Conversation 2016 https://theconversation.com/how-tony-blairfumbled-iraqs-child-mortality-statistics-62260. 